\title{
Grain-size effect on pressure-induced semiconductor-to-metal transition in ZnS
}

Jiang, Jianzhong; Gerward, Leif; Frost, D.; Secco, R.; Peyronneau, J.; Olsen, J.S.

Published in:

Journal of Applied Physics

Link to article, DOI:

10.1063/1.371631

Publication date:

1999

Document Version

Publisher's PDF, also known as Version of record

Link back to DTU Orbit

Citation (APA):

Jiang, J., Gerward, L., Frost, D., Secco, R., Peyronneau, J., \& Olsen, J. S. (1999). Grain-size effect on pressureinduced semiconductor-to-metal transition in ZnS. Journal of Applied Physics, 86(11), 6608-6610.

https://doi.org/10.1063/1.371631

\section{General rights}

Copyright and moral rights for the publications made accessible in the public portal are retained by the authors and/or other copyright owners and it is a condition of accessing publications that users recognise and abide by the legal requirements associated with these rights.

- Users may download and print one copy of any publication from the public portal for the purpose of private study or research.

- You may not further distribute the material or use it for any profit-making activity or commercial gain

- You may freely distribute the URL identifying the publication in the public portal

If you believe that this document breaches copyright please contact us providing details, and we will remove access to the work immediately and investigate your claim. 


\section{Grain-size effect on pressure-induced semiconductor-to-metal transition in $\mathrm{ZnS}$}

J. Z. Jiang ${ }^{\text {a) }}$ and L. Gerward

Department of Physics, Building 307, Technical University of Denmark, DK-2800 Lyngby, Denmark

D. Frost and R. Secco

Bayerisches Geoinstitut, Universität Bayreuth, D-95440 Bayreuth, Germany

J. Peyronneau

Laboratoire des Geomateriaux, Institut de Physique du Globe, 4 place Jussieu 75252

Paris cedex 05, France

J. S. Olsen

Niels Bohr Institute, Oersted Laboratory, DK-2100 Copenhagen, Denmark

(Received 26 April 1999; accepted for publication 12 August 1999)

The grain-size effect on the semiconductor-to-metal transition in $\mathrm{ZnS}$ has been investigated by in situ high-pressure electrical resistance and optical measurements. It is found that the grain-size effect can elevate the transition pressure of $\mathrm{ZnS}$ in a larger pressure range. On the basis of the results obtained and results reported in the literature, we demonstrate that the dangers of using the transition pressures of the II-VI compounds as pressure calibrators without a detailed knowledge of their grain-size effects on the transition pressures cannot be overstressed. (C) 1999 American Institute of Physics. [S0021-8979(99)03922-5]

The semiconductor-to-metal transitions in a few II-VI semiconductor compounds are used to establish the fixedpoint static pressure calibration curve in the pressure range from 15 to $25 \mathrm{GPa}$ for the multianvil high-pressure apparatus, which has been used in many disciplines, e.g., geoscience, materials science, and physics. ${ }^{1}$ Among them is the $\mathrm{ZnS}$ semiconductor, which has been investigated for many decades. ${ }^{2,3}$ Substantial discrepancy in the magnitude of the transformation pressure for $\mathrm{ZnS}$ reported in literature has been suggested due to three possible reasons: (1) the different techniques used to identify the transition; (2) various nonhydrostatic conditions in the different pressure apparates; and (3) different systematic errors of the pressure calibration at different groups. Here we report another factor, the grain size of crystals, which can influence the semiconductor-tometal transition pressure. We clearly show evidence that a reduction of the grain size can substantially elevate the transition pressure of $\mathrm{ZnS}$.

Three $\mathrm{ZnS}$ samples with average grain sizes of approximately $10 \mu \mathrm{m}, 36$, and $11 \mathrm{~nm}$, were investigated. $\mathrm{ZnS}$ powder $(10 \mu \mathrm{m})$ with a $99.9 \%$ purity was used as a starting material for the synthesis of nanometer-sized $\mathrm{ZnS}$ samples using a Planetary ball mill (Fritsch Pulverisette 5), with tungsten carbide vials and balls. A single phase with a sphalerite structure (B3) in the samples studied was confirmed by x-ray powder diffraction. The average grain sizes of milled samples and the starting material were estimated by $x$-ray powder diffraction and by scanning electron microscopy, respectively. High resolution transmission electron microscopy measurements revealed the presence of lattice fringes and confirmed the B3 structure in the samples. Tungsten con-

\footnotetext{
${ }^{a)}$ Author to whom correspondence should be addressed; electronic mail:
} jiang@fysik.dtu.dk tamination in the milled samples, originating from the abrasion of the vial and balls, was found to be less than 0.5 at. \% from the energy dispersive $\mathrm{x}$-ray analysis.

High-pressure in situ electrical resistance measurements at ambient temperature were carried out at Bayreuth, Germany in a 1200 ton multianvil apparatus using 10 and $7 \mathrm{~mm}$ edge length octahedral pressure cells. Copper foils were used as electrodes to measure the dc resistance across a sample disk of approximate dimensions $0.9 \mathrm{~mm}$ diameter and 0.5 $\mathrm{mm}$ thick. Resistance measurements were made on increasing pressure using a previously determined pressure calibration that is based on several pressure standards, including $\mathrm{ZnS}$. However, in this study, we are interested in the relative change in pressure, at which the semiconductor-to-metal

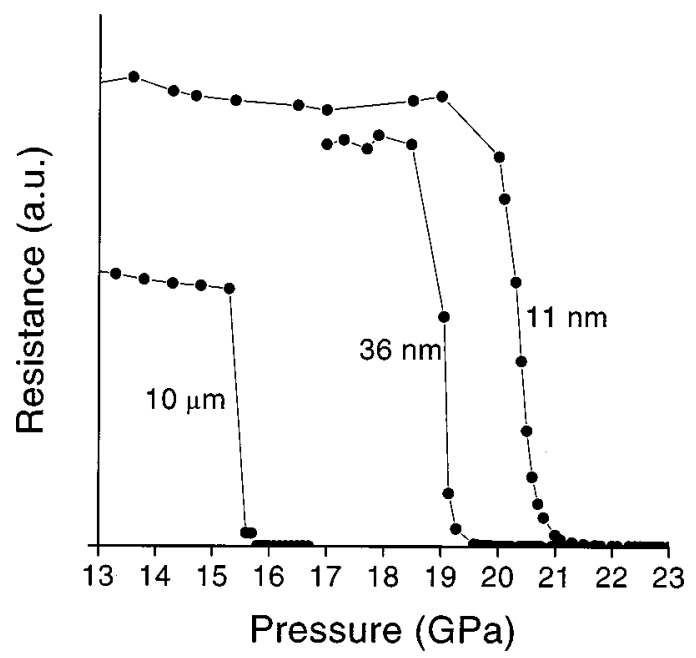

FIG. 1. High-pressure in situ electrical resistances for $\mathrm{ZnS}$ materials with average grain sizes of $10 \mu \mathrm{m}, 36$, and $11 \mathrm{~nm}$ at ambient temperature. 

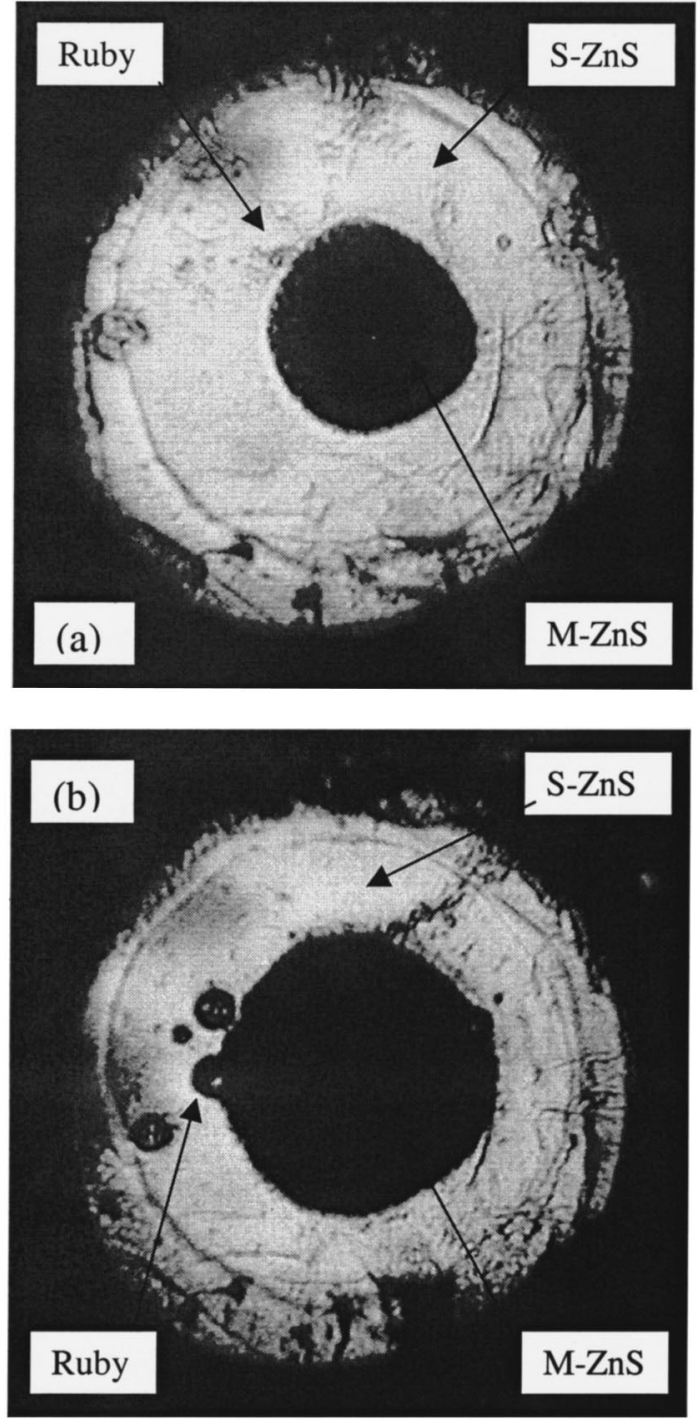

FIG. 2. High-pressure in situ optical micrographs of the semiconductor-tometal transitions for $\mathrm{ZnS}$ materials with average grain sizes of $10 \mu \mathrm{m}$ (a) and $11 \mathrm{~nm}(\mathrm{~b})$. The transition pressures were determined to be $21.8 \pm 0.6$ and $16.0 \pm 0.5 \mathrm{GPa}$ for $11 \mathrm{~nm}$ and $10 \mu \mathrm{m} \mathrm{ZnS}$ samples, respectively.

transition is observed for samples with different grain sizes.

High-pressure in situ optical measurements for $\mathrm{ZnS}$ materials with average grain sizes of $10 \mu \mathrm{m}$ and $11 \mathrm{~nm}$ were performed in a Mao-Bell type diamond anvil cell with 0.4 $\mathrm{mm}$ flat culet in Paris, France. The powder samples were directly compressed in a $0.4 \mathrm{~mm}$ hole of a nickel gasket without pressure transmitting medium. The pressure was measured by using small ruby chips placed on the top diamond. The high-pressure metallic phase $(\mathrm{M}-\mathrm{ZnS})$ is opaque compared with the low-pressure semiconducting phase $(\mathrm{S}-\mathrm{ZnS})$, so that the phase boundary is quite well defined. By increasing the applied load to the diamonds the limit of the high-pressure phase moves in the pressure gradient and the transition pressure was accurately measured when the phase boundary was just crossing a ruby chip.

Figure 1 shows high-pressure in situ electrical resistances for $\mathrm{ZnS}$ materials with average grain sizes of $10 \mu \mathrm{m}$, 36 , and $11 \mathrm{~nm}$. It is clearly seen that the semiconductor-to- metal transition occurs at pressures of approximately 19.0 \pm 0.4 and $20.5 \pm 0.6 \mathrm{GPa}$ for the 36 and $11 \mathrm{~nm} \mathrm{ZnS}$, respectively, whereas for the $10 \mu \mathrm{m} \mathrm{ZnS}$ it occurs at approximately $15.6 \pm 0.3 \mathrm{GPa}$. We further performed high-pressure optical measurements for the $11 \mathrm{~nm} \mathrm{ZnS}$ as well as the $10 \mu \mathrm{m}$ sample for comparison, as shown in Fig. 2. It is found that the semiconductor-to-metal transition for the $11 \mathrm{~nm} \mathrm{ZnS}$ [Fig. 2(b)] appears at around 21.8 $\pm 0.6 \mathrm{GPa}$ while the $10 \mu \mathrm{m}$ sample [Fig. 2(a)] has a transition at around $16.0 \pm 0.5 \mathrm{GPa}$, in good agreement with the data obtained in Fig. 1. Our experimental data reveal that the semiconductor-to-metal transition pressure strongly depends on the grain size of $\mathrm{ZnS}$ crystals. The smaller the crystal, the higher the transition pressure.

Recently, the issue of the effects of crystallite size on structural stability in nanocrystals has been shown to be of considerable interest from a fundamental viewpoint, and also with respect to the applicability of these materials. Over the last few years $\mathrm{x}$-ray powder diffraction using synchrotron radiation has been intensively applied to study the effects of crystallite size on structural stability in nanocrystals. Tolbert et l. $^{4-6}$ reported their studies on $\mathrm{Si}, \mathrm{CdSe}$, and $\mathrm{CdS}$ nanocrystals and found that the smaller the crystallite, the higher the transformation pressure. They explained the increase in transition pressure for the nanocrystals in terms of surfaceenergy differences between the phases involved. An enhancement of transition pressure in nanocrystals $\mathrm{ZnO}$ compared with corresponding bulk material was also observed. ${ }^{7}$ Qadri et al. ${ }^{8}$ have also reported that the effect of reduced particle size in $\mathrm{PbS}$ nanocrystals is to elevate the transition pressure while the compressibility increases with decreasing particle size. However, Jiang et al. ${ }^{9}$ reported that for nanometer-sized $\gamma-\mathrm{Fe}_{2} \mathrm{O}_{3}$ particles the phase transition pressure (from $\gamma-\mathrm{Fe}_{2} \mathrm{O}_{3}$ to $\alpha-\mathrm{Fe}_{2} \mathrm{O}_{3}$ ) is lower than for bulk material. A similar result was also reported in $\mathrm{TiO}_{2}$ for the rutile-to- $\alpha-\mathrm{PbO}_{2}$ transition. ${ }^{10}$ The authors suggested the larger volume change upon transition in the nanocrystals than in bulk being the main factor. It seems that the grainsize effect on the structural stability can be of either sign with respect to the change of the transition pressure, depending on the system under investigation.

On the basis of the results obtained for the $\mathrm{ZnS}$ samples and results reported in the literature, therefore, it can be concluded that the dangers of using the transition pressures of the II-VI semiconductor compounds as pressure calibrators without a detailed knowledge of their grain-size effects on the transition pressures cannot be overstressed.

Financial support from the Danish Technical Research Council, the Danish Natural Science Research Council, and the "Large Scale Facility" program at the Bayerisches Geoinstitut is gratefully acknowledged.

\footnotetext{
${ }^{1}$ Y. Xu, B. T. Poe, T. J. Shankland, and D. C. Rubie, Science 280, 1415 (1998).

${ }^{2}$ W. H. Gust, J. Appl. Phys. 53, 4843 (1982).

${ }^{3}$ M. J. Walter, Y. Thibault, K. Wei, and R. W. Luth, Can. J. Phys. 73, 273 (1995), and references therein.

${ }^{4}$ S. H. Tolbert and A. P. Alivisatos, Science 265, 373 (1994).
} 
${ }^{5}$ S. H. Tolbert and A. P. Alivisatos, J. Chem. Phys. 102, 4642 (1995).

${ }^{6}$ S. H. Tolbert, A. B. Herhold, L. E. Brus, and A. P. Alivisatos, Phys. Rev. Lett. 76, 4385 (1996).

${ }^{7}$ J. Z. Jiang, J. Staun Olsen, and L. Gerward (unpublished).

${ }^{8}$ S. B. Qadri, J. Yang, B. R. Ratna, E. F. Skelton, and J. Z. Hu, Appl. Phys.
Lett. 69, 2205 (1996).

${ }^{9}$ J. Z. Jiang, J. Staun Olsen, L. Gerward, and S. Mørup, Europhys. Lett. 44, 620 (1998).

${ }^{10}$ J. Staun Olsen, L. Gerward, and J. Z. Jiang, J. Phys. Chem. Solids 60, 229 (1999). 